\title{
Profound thrombocytopenia and generalized hyperpigmentation following pyrimethamine use
}

\author{
Manouri P Senanayake ${ }^{1}$, D S G Mettananda ${ }^{2}$, Sudharma Vidyatilake ${ }^{3}$ \\ Sri Lanka Journal of Child Health, 2011; 40: 134-135
}

(Keywords: Pyrimethamine; profound thrombocytopenia; hyperpigmentation)

DOI: http://dx.doi.org/10.4038/sljch.v40i3.3513

Pyrimethamine is an effective anti-parasitic medication with a narrow therapeutic index. We report a child with toxoplasmosis who developed hyperpigmentation and profound thrombocytopenia during a course of treatment with pyrimethamine. These two unusual complications occurred in addition to folate deficiency and megaloblastic anaemia which are recognized adverse effects of this medication.

\section{Case report}

A seven year old girl, weighing $20 \mathrm{~kg}$, presented with rapidly progressive generalized hyperpigmentation and lethargy of two weeks duration. Multiple ecchymotic patches had appeared on the day of admission. She was ingesting a daily dose of pyrimethamine as treatment for toxoplasmosis with multi-system involvement. Toxoplasmosis had been diagnosed because of cervical lymphadenopathy and hepatosplenomegaly of two years duration, progressive peripheral eosinophilia and high titre of toxoplasma specific IgM antibodies. There was no choreoretinitis. A twenty one day course of pyrimethamine was administered starting with a loading dose of $40 \mathrm{mg}(2 \mathrm{mg} / \mathrm{kg} /$ day $)$ on two consecutive days followed by a daily dose of $20 \mathrm{mg}$ $(1 \mathrm{mg} / \mathrm{kg} /$ day $)$. She had taken pyrimethamine for a total of 17 days without complying with prophylactic folic acid $5 \mathrm{mg}$ daily.

On physical examination she looked ill and apathetic. She was afebrile and had oral ulcers and large ecchymoses over trunk and limbs. There was

\footnotetext{
${ }_{1}^{1}$ Professor in Paediatrics, University of Colombo, ${ }^{2}$ Registrar, Lady Ridgeway Children's Hospital, Colombo, ${ }^{3}$ Consultant Haematologist, Lady Ridgeway Children's Hospital, Colombo
}

(Received on 6 September 2010: Accepted on 29 October 2010) hyperpigmentation of the skin more marked in the extremities and in palms, soles, skin creases and buccal mucosa. Blood pressure was normal. Hepatosplenomegaly and lymphadenopathy had reduced in size. Full blood count showed a haemoglobin of $8.6 \mathrm{~g} / \mathrm{dl}$, a platelet count $10 \times 10^{9} / \mathrm{L}$ and a white cell count of $8.5 \times 10^{9} / \mathrm{L}$. There were oval macrocytic erythrocytes and hyper-segmented neutrophils in the blood picture with reduced platelets and no blast cells. Bone marrow biopsy was performed after platelet transfusion and before any other intervention. Marrow confirmed megaloblastic anaemia, while showing megakaryocytes that were increased in number and activity. Large megakaryocyte with increased budding are shown in Figure 1.

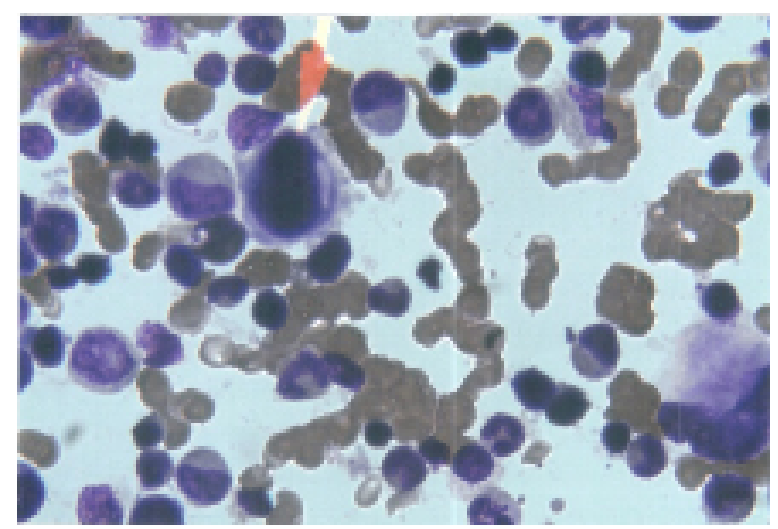

Figure 1: Bone marrow showing megakaryocyte with increased platelet budding

Red blood cell folate level was $36.6 \mathrm{ng} / \mathrm{ml}$ (normal range: $252.6-813.7 \mathrm{ng} / \mathrm{ml}$ ) and serum $\mathrm{B}_{12}$ level was $908.9 \mathrm{pg} / \mathrm{ml}$ (normal range: 208 - $963 \mathrm{pg} / \mathrm{ml}$ ). Serum electrolytes, blood glucose, liver enzymes and serum creatinine were normal.

Pyrimethamine was discontinued and a thrice daily dose of folic acid $5 \mathrm{mg}$ started. On the seventh day after stopping pyrimethamine a normal platelet count 
was regained. By three weeks, haemoglobin was $11.2 \mathrm{~g} / \mathrm{dl}$ and the oral ulcers resolved completely. Hyperpigmentation began fading only after two months. At four months, apart from a firm spleen of $1.5 \mathrm{~cm}$ below the costal border, she was completely well.

\section{Discussion}

Our patient developed hyperpigmentation, acute profound thrombocytopenia, megaloblastic anaemia and folate deficiency while on pyrimethamine. Although pigmentation is described in some patients with megaloblastic anaemia it is very rare following pyrimethamine use and the few reported cases are in adults ${ }^{1,2,3}$.

Four children previously reported to develop hyperpigmentation while on pyrimethamine all had AIDS and were receiving azidothymidine, pyrimethamine and ketoconazole, causing uncertainty regarding which medication had caused hyperpigmentation ${ }^{4}$.

Megaloblastic anaemia due to folate deficiency caused by pyrimethamine-induced enzyme inhibition is associated with mild to moderate thrombocytopenia but profound life threatening thrombocytopenia is very rare. Pancytopenia is another haematological complication but we found normal white cell counts ${ }^{5}$.

Bone marrow showed increased megakaryocytic activity (figure 1) suggesting a peripheral destruction of platelets rather than a reduced production due to folate deficiency. A diagnosis of immune thrombocytopenia was considered and we found that this complication has been reported once before after pyrimethamine. Recovery in seven days of stopping pyrimethamine was in keeping with the mean recovery period (8 days) of drug induced thrombocytopenia ${ }^{6}$.

This case report demonstrates that pyrimethamine can cause severe thrombocytopenia and generalized hyperpigmentation with significantly low folate levels.

\section{Acknowledgement}

We thank Dr. Lalindra Gooneratne, Senior Lecturer, Faculty of Medicine Colombo for assisting with photomicrography.

\section{References}

1. Baker SJ, Mathan VI, Abe K. Beta-melanocyte stimulating hormone levels in subjects with hyperpigmentation associated with megaloblastic anaemia. Blood 1970; 35(1):83-5.

2. Bulugahapitiya DUS, de Silva C, Suthanson R. Drug induced megaloblastic anaemia with abnormal skin pigmentation. Ceylon Medical Journal 2002; 47(3): 99-100.

3. Ozturk R, Engin A, Ozaras R, Mert A, Tabak F, Aktuglu Y. Hyperpigmentation due to pyrimethamine use. Journal of Dermatology 2002; 29(7):443-5.

4. Poizot-Martin I, Lafeuillade A, Dhiver C, Xeri L, Bouabdallah R, Cutaneo-mucosal hyperpigmentation in AIDS: 4 cases. Presse Medicale 1991; 20(14):632-6

5. Kachel L, Krawczyk-Kuliś M, Hołowiecki J. Pancytopenia as a complication of the treatment of toxoplasmosis. Polski tygodnik lekarski 1992; 47(5-6): 136-7.

6. Pedersen-Bjergaard U, Andersen M, Hansen PB. Drug-induced thrombocytopenia: clinical data on 309 cases and the effect of corticosteroid therapy. European Journal of Clinical Pharmacology 1997; 52(3): 183-9. http://dx.doi.org/10.1007/s002280050272 